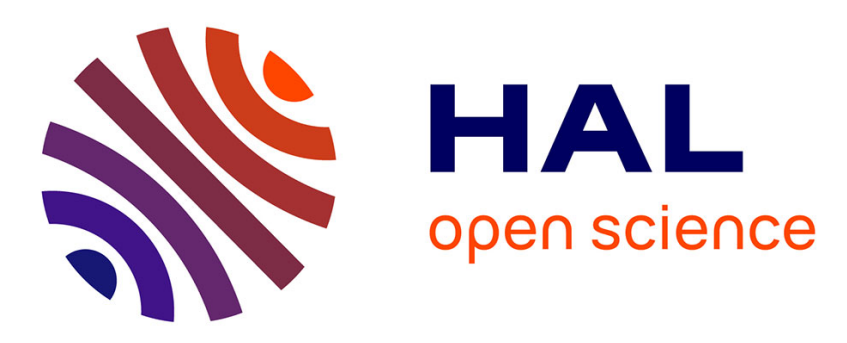

\title{
Repair of Bone Tissue Affected by Osteoporosis with Hydroxyapatite-Poly-L-lactide (HAp-PLLA) With and Without Blood Plasma
}

Z. Ajduković, S. Najman, Lj Đorđević, V. Savić, D. Mihailović, D. Petrović, N. Ignjatović, D. Uskoković

\section{To cite this version:}

Z. Ajduković, S. Najman, Lj Đorđević, V. Savić, D. Mihailović, et al.. Repair of Bone Tissue Affected by Osteoporosis with Hydroxyapatite-Poly-L-lactide (HAp-PLLA) With and Without Blood Plasma. Journal of Biomaterials Applications, 2005, 20 (2), pp.179-190. 10.1177/0885328205050519 . hal00570761

\section{HAL Id: hal-00570761 \\ https://hal.science/hal-00570761}

Submitted on 1 Mar 2011

HAL is a multi-disciplinary open access archive for the deposit and dissemination of scientific research documents, whether they are published or not. The documents may come from teaching and research institutions in France or abroad, or from public or private research centers.
L'archive ouverte pluridisciplinaire HAL, est destinée au dépôt et à la diffusion de documents scientifiques de niveau recherche, publiés ou non, émanant des établissements d'enseignement et de recherche français ou étrangers, des laboratoires publics ou privés. 


\title{
Repair of Bone Tissue Affected by Osteoporosis with Hydroxyapatite-Poly-L-lactide (HAp-PLLA) With and Without Blood Plasma
}

\author{
Z. AJDUKOVIĆ \\ Faculty of Medicine, Clinic of Stomatology \\ Department of Prosthodontics, Niš, Serbia and Montenegro
}

S. NAJMAN AND LJ ĐORĐEVIĆ

Faculty of Medicine, Institute of Biology, Niš, Serbia and Montenegro

\section{SAVIĆ}

Faculty of Medicine, Nišs, Institute of Biochemical Research, Niš, Serbia and Montenegro

D. MiHAILOviĆ

Faculty of Medicine, Institute of Pathology, Niš, Serbia and Montenegro

D. Petrović

Faculty of Medicine, Clinic of Stomatology

Department of Maxillofacial Surgery, Niš, Serbia and Montenegro

\section{N. IGNJATOVIĆ AND D. UsKoKoviĆ*}

Institute of Technical Sciences of the Serbian Academy of Sciences and Arts K. Mihailova 35/IV, 11000, Belgrade, Serbia and Montenegro

\footnotetext{
*Author to whom correspondence should be addressed. E-mail: uskok@itn.sanu.ac.yu 


\begin{abstract}
The aim of this study is to examine the reparatory ability of the synthetic biomaterial hydroxyapatite-poly-L-lactide (HAp-PLLA), the replacement of alveolar ridge, and rehabilitation of bone defects caused by osteoporosis, in an experimental group of animals. The experiments are performed on syngeneic Sprague Dawley rats. Osteoporosis is induced by glucocorticoids in rats during a 12-week period. After this, the experimental group of animals is divided into five subgroups. An artificial defect is made in the alveolar bone on the left side of the mandible. In one group of animals, the defect is left to heal by itself, while in other groups, pure HAp-PLLA or one mixed with plasma is implanted. The best results are achieved by the implantation of the HAp-PLLA composite biomaterial mixed with autologous plasma. Formation of a new mandibular bone is seen, growing intensely, leading to rapid osteogenesis.
\end{abstract}

KEY WORDS: reparation, mandible, rat, osteoporosis, hydroxyapatitepoly-L-lactide.

\title{
INTRODUCTION
}

$\mathbf{O}$ ral rehabilitation of patients with tissue defects that occur due to the advanced bone resorption of residual alveolar ridge, trauma, irradiation, and surgical operations in the region of the face and jaws, represents a common task in modern stomatology [1-3]. Particular attention has been given to osteoporosis of the alveolar bone that occur due to the rapid resorption of bone tissue or the insufficient synthesis of bones, induced by glucocorticoids or by certain chronic diseases [4]. One of the procedures for the treatment of these problems is oral implantology with the application of various types of biomaterials. Special interest is given nowadays to synthetic biomaterials such as ceramicspolymer composites that resemble natural bone in oral implantology [5]. Biomaterials based on synthetic hydroxyapatite and biocompatible polymer are representatives of this type [6-8]. Hydroxyapatite (HAp) is the most commonly used ceramic biomaterial for the restoration and regeneration of bones. The most important feature of hydroxyapatite is its chemical similarity to the mineralized phase of bones. This similarity is based on its osteoconductive potential and excellent biocompatibility. Hydroxyapatite is an excellent carrier of osteoinductive growth factors and osteogenic cell population, which significantly increases its usefulness as a bioactive material of the future. Polymers are very important substrates for the distribution of bioactive molecules [9-11]. It has been shown that the introduction of HAp into poly-L-lactide (PLLA) improves the bonding of the material to the bones [12].

Many studies analyzing the application of HAp-PLLA composites, have been published so far. Our previous studies established that bioresorption of the PLLA polymer phase and generation of collagen 
fibers were taking place at the sites of bioresorption of PLLA after intraperitoneal implantation [13]. The same final results as in the case of the HAp-PLLA composite biomaterial used alone, were found after the intraperitoneal implantation of a mixture of bone powder and the HAp-PLLA composite. The HAp-PLLA composite material was successfully used in the form of rods and tested for internal fixation of bone fractures [14-16].

This paper analyzes the reconstructive possibilities of the bone tissues of the mandible with the HAp-PLLA composite biomaterial. The novelty, compared to previous research, is that it examined possibility of HAp-PLLA composite biomaterial application with and without plasma, which is the source of different growth factors in the mandibular alveolar bone damaged by osteoporosis in in vivo conditions.

\section{MATERIALS AND METHODS}

Six to eight-week-old syngeneic female Sprague Dawley rats, who had attained sexual maturity and mineralization of bones were examined. Osteoporosis was induced by glucocorticoids. The animals were initially divided into two groups. One control group (A, 12 animals) was without therapy and on a normal regime of diet. Another group (B, 30 animals) was successively treated with intramuscular glucocorticoids: methylprednisolone (Lemod-Solu, Hemofarm, Vršac) in a dose of $2 \mathrm{mg} / \mathrm{kg}$ of body mass; dexamethasone (Dexason, ICN Galenika Belgrade) in a dose of $0.2 \mathrm{mg} / \mathrm{kg}$. Each medicament was given every second day. Glucocorticoids were administered always at the same time, from 2 to 5 p.m., when the level of cortisol in the blood was the highest. So the animals had the minimum reaction to stress. At the end of the treatment with glucocorticoids, three subgroups of six rats were formed.

In the subgroups of rats, a defect $1.6 \mathrm{~mm}$ in diameter and $1.8 \mathrm{~mm}$ in depth, was made in the region between the medial line and the mental foramen on the left side of the mandible by a sterile steel boring machine.

The bone defect in the rats from subgroup B1 was left to heal naturally, while in another two subgroups, biomaterials were implanted into the defect.

Rats of subgroup B2 (HAp-PLLA) were implanted with the HApPLLA composite biomaterial, with PLLA of 430.000 mole mass, obtained by a two-step chemical procedure published in detail in our earlier studies [6-8].

Animals of subgroup B3 (HAp-PLLA-PL) were implanted with the composite previously submerged in autologous plasma. Blood from 
the heart of the specimen was centrifuged at $1500 \mathrm{rpm}$. The separated plasma was mixed with granules of the composite biomaterial in a ratio $1: 1$. The material was implanted into the alveolar bone of the rat, damaged by osteoporosis. The process was repeated for each animal separately.

The postoperative course was the same in all animals. They were followed up from three to six months (12-24 weeks) after implantation, and then sacrificed.

Alveolar bone from the region of the artificial defect of the mandible was taken for analysis. The bone was rinsed with a physiological solution, then fixed in 10\% formalin and decalcified by electrolysis in a solution of concentrated formic acid for 10-12 h. After decalcification, the bone tissue was treated, followed by molding, cutting, and staining by the hemotoxylin-Eosin (HE) method.

The histological preparations obtained were histomorphometrically analyzed by an image analysis system, Lucia $32 \mathrm{G}$ (Laboratory Imaging, Prague, Czech Republic) on a microscope (LEICA DMR) with 10× magnification $(\mathrm{NA}=0.5)$ and a digital camera (with $640 \times 480$ pixels). After defining the test field, the area (surface of part of the bone which was seen on defined visual field), the area box (percentage of visual field occupied by a new bone structure), and the mean density of the examined part of the picture of the bone tissue, of both compact and spongy bones of the mandible, were determined.

MANOVA and $t$-test were used for the statistical analysis of the obtained data and the values were presented as the mean value and the standard deviation.

\section{RESULTS}

Twelve weeks after the implantation of HAp-PLLA-PL composites, formation and integration of new bone tissue was found (Figure 1) in the B3 subgroup. On the other hand, twelve weeks after implantation of HAp-PLLA composites, a junction line between the existing and the newly formed bone was noticed on several spots. Spaces created by resorption of the implant material were noticed. These spaces were only partially filled with the new bone tissue. Residues of connective tissue, fibroblasts, and fibrocytes were observed in such areas (Figure 2). In the bones of untreated rats, strong osteogenesis occurred. New bone tissue almost filled the defect (Figure 3).

Twenty-four weeks after implantation, a considerably higher intensity of osteogenesis and a more regular bone structure were noticed in rats of HAp-PLLA and HAp-PLLA-PL subgroups B2 and B3, in relation to all 


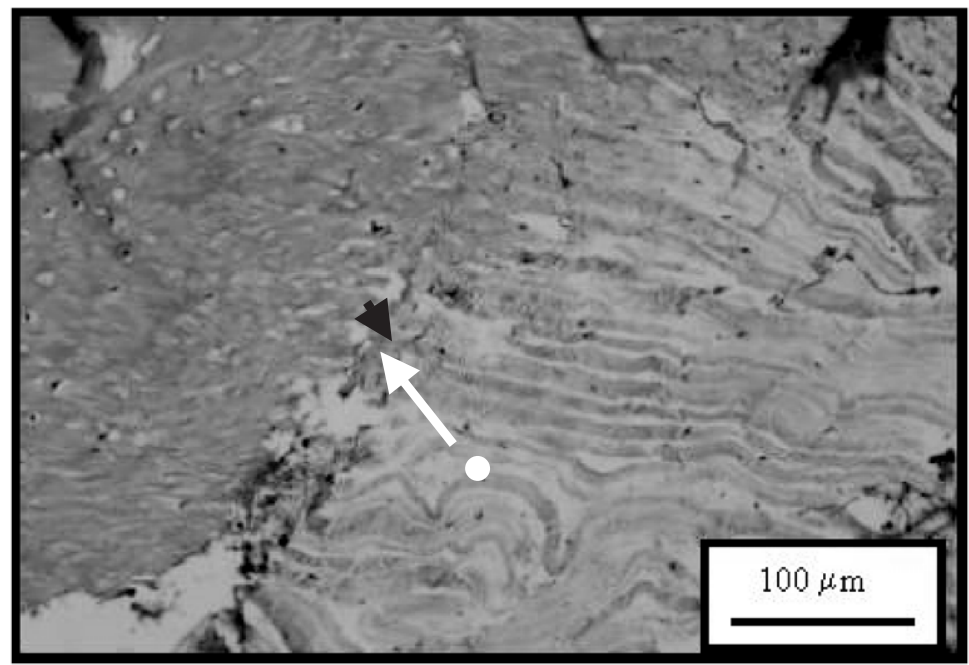

Figure 1. More intensive formation of a new bone twelve weeks after the implantation of HAp-PLLA-PL composite with plasma - subgroup B3 ( $\triangle$ is located at the interface of material residue and newly formed bone tissue and it points to the newly formed bone tissue; $\circ$ is located at the place of implanted material residue).

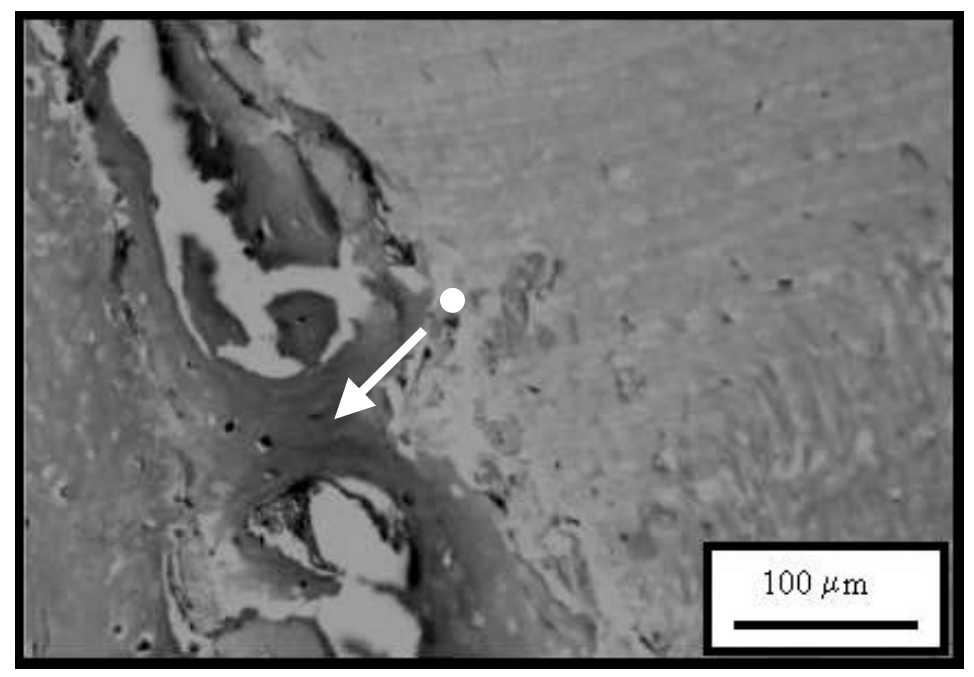

Figure 2. Formation of a new bone twelve weeks after implantation of HAp-PLLA composite - subgroup B2 ( $\triangle$ is located at the interface and it points to the newly formed bone tissue; $\circ$ is located at the place of the implanted material residue). 


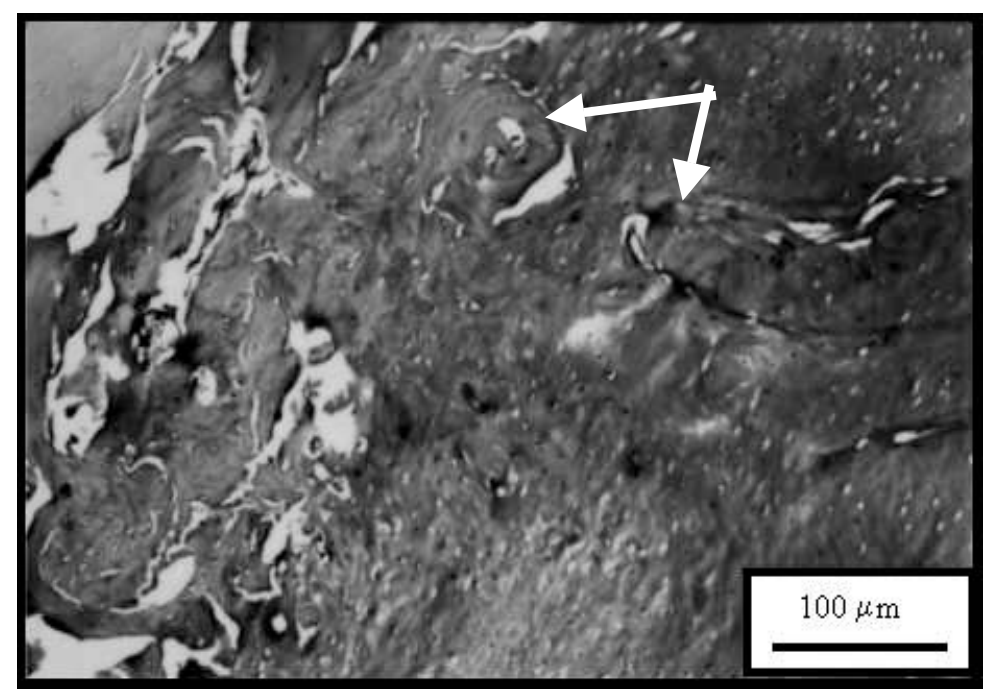

Figure 3. Healing of the artificial defect in normal rat alveolar bone- group A ( $\triangle$ signifies Havers' system and cement lines in osteogenesis and healing of the defect made in healthy alveolar bone).

other subgroups (Figures 4 and 5). In the subgroup with experimentally induced osteoporosis, the bone defect was not filled with a new bone (Figure 6).

In both spongy and compact bones of the rat mandible, statistically significant differences $(p<0.05)$ in the area, area box, and mean density between the control group and the subgroup of experimental animals, which were implanted with HAp-PLLA-PL composite subgroup B3, were found. On the other hand, only the difference in area box between the control group A and the subgroup, which were implanted with HAp-PLLA-subgroup B2 was statistically significant (Tables 1 and 2).

\section{DISCUSSION}

Six to eight-week-old healthy Sprague Dawley rats who attained sexual maturity and mineralization of bones, were used as control in our experiments. So the morphology of both compact and spongy parts of the alveolar bone, as well as the process of formation of new bone tissues in the location of the defect was taken for comparison with that of the other experimental groups $[1,3,4]$. In these animals, newly formed Haversian systems with cement lines in compact bone within the defect, as well as reduction of the size of marrow spaces in spongy bone in comparison to 


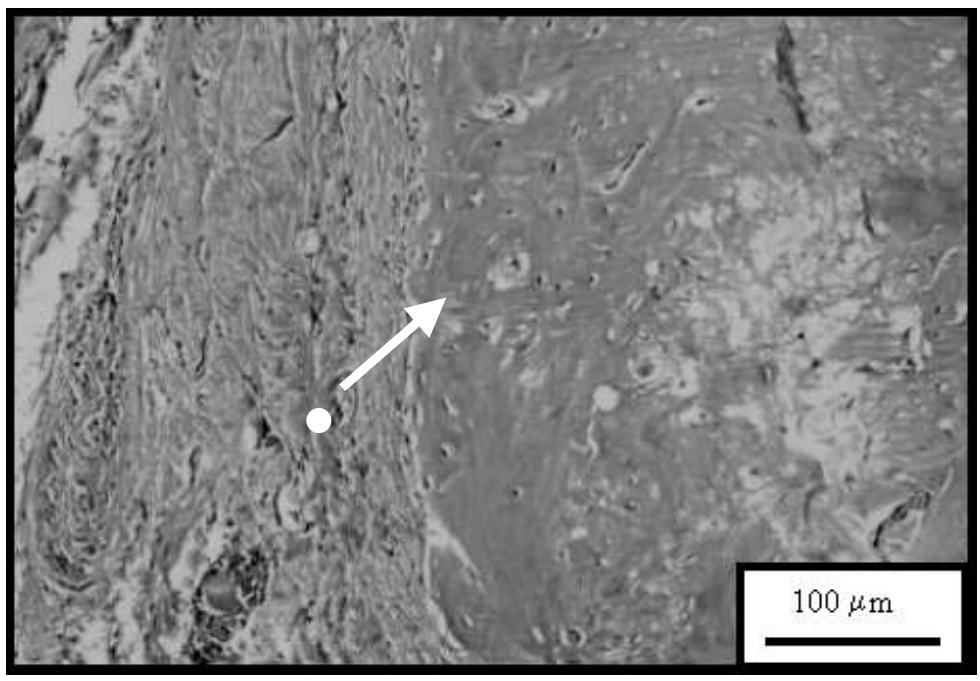

Figure 4. More intensive formation of new bone twenty four weeks after implantation of HAp-PLLA-PL composite with plasma - subgroup B3 $(\triangle$ points to the intensive osteogenesis, i.e., newly formed healthy bone tissue and $\circ$ is located at the place where connecting tissue and blood vessels substituted the implanted material residue).

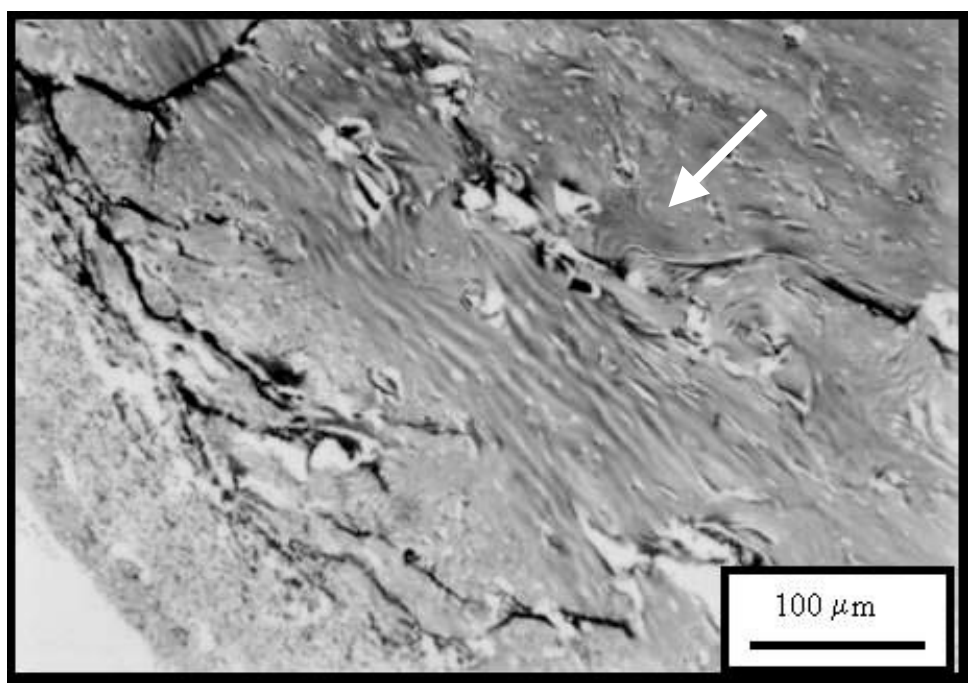

Figure 5. Formation of a new bone twenty four weeks after implantation of HAp-PLLA composite - subgroup B2 ( $\triangle$ points to layered sediment of newly formed bone tissue rich with blood vessels and the implanted material residue is dimly sighted in the lower left corner of the figure). 


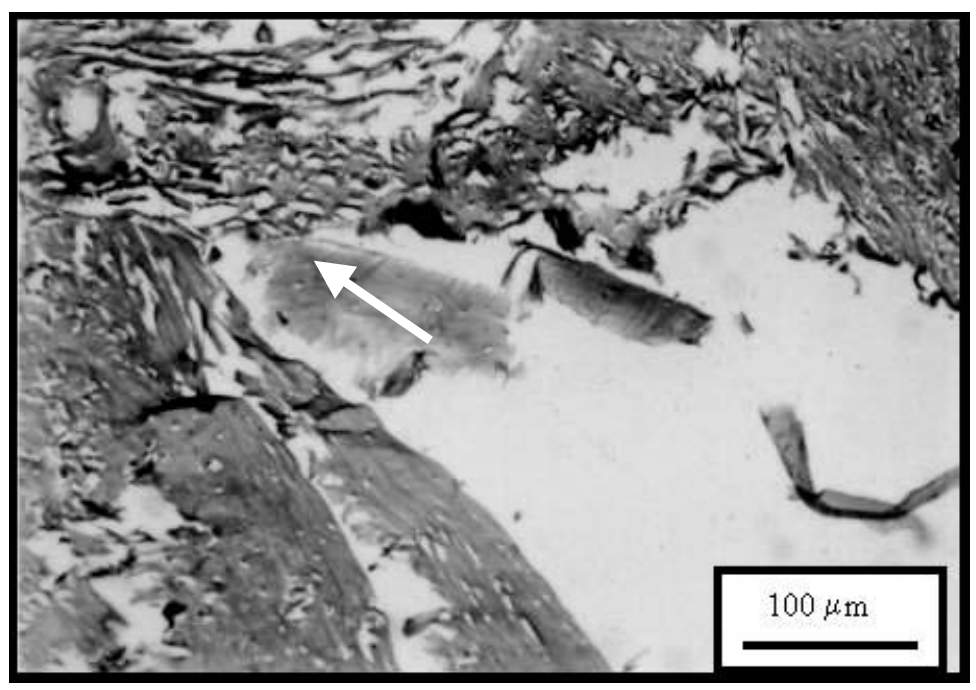

Figure 6. Artificial defect in osteoporotic rat alveolar bone - subgroup B1 ( $\triangle$ points to the beginning of the newly formed bone tissue genesis within the defect of the alveolar bone of the rat, damaged by osteoporosis).

Table 1. Histomorphometrical analysis of the spongy bone of mandible in experimental animals, 12 weeks after implantation.

\begin{tabular}{|c|c|c|c|c|c|c|c|}
\hline \multirow[b]{2}{*}{$\begin{array}{l}\text { Examined } \\
\text { parameters }\end{array}$} & \multirow{2}{*}{$\begin{array}{c}\begin{array}{c}\text { Control } \\
\text { group (A) }\end{array} \\
\begin{array}{c}\mathrm{A} \\
(n=6)\end{array}\end{array}$} & \multicolumn{6}{|c|}{ Experimental group (B) } \\
\hline & & $\begin{array}{c}\mathrm{B} 1 \\
(n=6)\end{array}$ & $t$-Test & $\begin{array}{c}\text { B2 } \\
(\text { HAp-PLLA) } \\
(n=6)\end{array}$ & $t$ - Test & $\begin{array}{c}\text { B3 } \\
(\text { HAp-PLLA-PL) } \\
(n=6)\end{array}$ & $t$-Test \\
\hline Area $\left(\mu / \mathrm{m}^{2}\right)$ & $914.32 \pm 304.78$ & $516.68 \pm 172.23$ & n.s. & $802.44 \pm 268.81$ & n.s. & $1101.88 \pm 367.29$ & $P<0.05$ \\
\hline Area box (\%) & $3.18 \pm 1.06$ & $2.08 \pm 0.69$ & n.s. & $4.54 \pm 10.51$ & $p<0.05$ & $4.71 \pm 1.57$ & $p<0.05$ \\
\hline $\begin{array}{l}\text { Mean density } \\
\text { (a.u.) }\end{array}$ & $1.96 \pm 0.66$ & $1.12 \pm 0.37$ & n.s. & $1.26 \pm 0.42$ & n.s. & $2.66 \pm 0.88$ & $p<0.05$ \\
\hline
\end{tabular}

the bone outside the defect (Figure 3) were noticed. After twelve weeks' healing, as bone filled the defect, it was not necessary to follow up these animals for a longer period of time than had been planned, as was the case with the other experimental groups. It was obvious that healing was going on rapidly and effectively without additional stimulation of osteogenesis by implantation of the biomaterial $[3,4]$.

Glucocorticoids applied to rats during the period of intensive growth, development, and bone mineralization showed several effects. It was noticed that the spongy bone became thinner, reduced, and more hollow. 
Table 2. Histomorphometrical analysis of compact bone of mandible in experimental animals, 12 weeks after implantation

\begin{tabular}{|c|c|c|c|c|c|c|c|}
\hline \multirow[b]{2}{*}{$\begin{array}{l}\text { Examined } \\
\text { parameters }\end{array}$} & \multirow{2}{*}{$\begin{array}{c}\begin{array}{c}\text { Control } \\
\text { group }(A)\end{array} \\
\begin{array}{c}\text { A } \\
(n=6)\end{array}\end{array}$} & \multicolumn{6}{|c|}{ Experimental group (B) } \\
\hline & & $\begin{array}{c}\text { B1 } \\
(n=6)\end{array}$ & $t$-Test & $\begin{array}{c}\text { B2 } \\
\text { (HAp-PLLA) } \\
(n=6)\end{array}$ & $t$-Test & $\begin{array}{c}\text { B3 } \\
\text { (HAp-PLLA-PL) } \\
(n=6)\end{array}$ & $t$-Test \\
\hline Area $\left(\mu / m^{2}\right)$ & $996.69 \pm 332.23$ & $514.12 \pm 171.37$ & n.s. & $783.36 \pm 261.12$ & n.s. & $1465.76 \pm 488.59$ & $p<0.05$ \\
\hline Area box (\%) & $3.23 \pm 1.08$ & $2.58 \pm 0.86$ & n.s. & $4.56 \pm 1.52$ & $p<0.05$ & $4.78 \pm 1.59$ & $p<0.05$ \\
\hline $\begin{array}{l}\text { Mean density } \\
\quad \text { (a.u.) }\end{array}$ & $2.04 \pm 0.68$ & $1.98 \pm 0.66$ & n.s. & $2.32 \pm 0.74$ & n.s. & $2.94 \pm 0.98$ & $p<0.05$ \\
\hline
\end{tabular}

The compact bone thereby became poorly mineralized, thin, and weak. The above-mentioned changes indicate the inhibition of the bone tissue formation and domination of catabolism process in comparison to bone anabolism processes [3].

In the group of glucocorticoid-treated rats, where the defect was made without filling with implant material, it was noticed that healing of bone tissue had begun, but the defect itself was not filled with new bone (Figure 6). This indicates that the osteoconductive effect of the biomaterial, similar to the examined ones, is necessary for higher levels of osteogenesis and complete healing. In the subgroup where HApPLLA composite was implanted, 24 weeks after implantation, besides intensive formation of a new bone, increased binding, as well as migration and distribution of vascular and osteogenic cells within remnants of implanted material were noticed, which confirmed the osteoconductive effect of that biocomposite [9-14].

Biostimulation of the healing process and strengthening of the altered osteoporotic alveolar bone were most intensely induced by HAp-PLLAPL composite mixed with autologous plasma. Some studies have already reported that a combination of HAp with plasma enriched in platelets, caused more rapid and high-grade regeneration of bone on the surface, where an alveolar defect was made [10-12,18] Considerably higher intensity of osteogenesis in rats of this subgroup, in comparison to the subgroup that was implanted with HAp-PLLA biocomposite, is probably the consequence of the activity of growth factors that were present in autologous plasma and that significantly improved cell proliferation, differentiation, and formation of a new bone $[17,18]$. It is possible that growth factors from autologous plasma initiate a complex cascade of endochondral bone formation. There are many data showing that bone morphogenetic protein recruit mesenchymal stem cells in the region of 
defect by means of hemotaxis and initiate their rapid proliferation and differentiation into chondroblasts and chondrocytes. These cells later enter the cartilage-like matrix, which is calcified into bone. Such tissue is later remodeled, forming mature lamellar bone that contains active elements of bone marrow [17,18].

The obtained data show that histomorphometric parameters (area, area box, and mean density) may be used for the precise determination of the healing abilities of the biocomposite materials in the fixation of bone fractures [15].

Generally, the examined synthetic biomaterials have shown osteoconductivity, enabling formation, organization of osteons, and Haversian canals similar to a normal bone. The results of the study confirm that new synthetic HAp-PLLA composite belongs to a group of biomaterials that makes the formation of a new bone easier and successfully replaces bone tissue with regard to its osteoconductive effect. The above-stated characteristics make that biocomposite, which has not been used in oral implantology and prosthetics so far, the material of choice that may be very valuable in future in cases of defects occurring due to osteoporosis of the alveolar bone.

\section{CONCLUSIONS}

Our histopathological and morphometric examinations have shown that the HAp-PLLA biocomposite represents a good osteoconductive material. This is proved by the intensive growth of new bone tissue in the compact and spongy parts of the mandible. The best healing results have been achieved by the implantation of HAp-PLLA-PL composite mixed with autologous plasma, because the greatest intensity of osteogenesis and the most regular bone structure had been noticed there, in comparison to all other examined groups of rats. Such results suggested that growth factors from plasma could contribute to suitable reparatory effects. Therefore, a biomaterial based on HAp and polymer that was examined in this study, may be of great importance in future for the healing of osteoporotic alveolar bone.

\section{ACKNOWLEDGMENTS}

This work was supported by the Serbian Ministry of Science and Technology under Project No. 1431: Molecular designing of monolith and composite materials. The authors thank Prof. Dr A. Dimic for his helpful comments and discussion. 


\section{REFERENCES}

1. Paschalis, E.P., Betts, F., DiCarlo, E., Mendelsohn, R. and Boskev, A.L. (1997). FTIR Microspectroscopic Analysis of Normal Human Cortical and Trabecular Bone, Calcif. Tissue. Int., 61(6): 480-486.

2. Stentz, W.C., Mealey, B.L., Gunsolley, J.C. and Waldrop, T.C. (1997). Effects of Guided Bone Regeneration Around Commercially Pure Titanium and Hydroxyapatite-coatad Dental Implants, II. Histologic analysis, J. Periodontol., 68(10): 933-949.

3. Fujita, T. (1997). Osteoporosis: Past, Present and Future, Osteoporosis Int., $\mathbf{7}(3): 19-27$.

4. Suda, T. and Miyaura, C. (1997). Pathogenesis of Bone Loss due to Estrogen Deficiency, Osteoporosis Int., 7(3): 43-46.

5. Hench, L. (1998). Bioceramics, J. Am. Ceram. Soc., 81: 1705-1728.

6. Ignjatovic, N., Tomic, S., Dakic, M., Miljkovic, M., Plavsic, M. and Uskokovic, D. (1999). Synthesis and Properties of Hydroxyapatite/Poly-Llactide Composite Biomaterials, Biomaterials, 20: 809-816.

7. Ignjatovic, N., Plavsic, M., Miljkovic, M., Zivkovic, Lj and Uskokovic, D. (1999). Microstructural Characteristic of Ca-Hydroxyapatite/Poly-L-lactide based Composites, J. Microsc., 196: 243-248.

8. Ignjatovic, N., Suljovrujic, E., Budimski, J., Krakovsky, I. and Uskokovic, D. (2004). Evaluation of Hot Pressed Hydroxyapatite/Poly-L-lactide Composite Biomaterial, Journal of Biomedical Materials Research Part B: Applied Biomaterials, 71B: 284-294.

9. Furukawa, T., Matsusue, Y., Nakagawa, Y., Shikinami, Y., Okuno, M. and Nakamura, T. (2000). Bone Bonding Ability of a New Biodegradable Composite for Internal Fixation of Bone Fractures, Clinical Orthopaedics and Related Research, 379: 247-258.

10. De Aza, P.N., Lukulinska, Z.B., Santos, C., Guitian, F. and De Aza, S. (2003). Mechanism of Bone-like Formation on a Bioactive Implant in vivo, Biomaterials, 24: 1437-1445.

11. Heidemann, W., Jeschkeit, S., Ruffieux, K., Fischer, J.H., Wagner, M., Krüger, G., Wintermantel, E. and Gerlach, K.L. (2001). Degradation of Poly (D,L)lactide Implants With or Without Addition of Calciumphosphates in vivo, Biomaterials, 22: 2371-2381.

12. Yasunaga, T., Matsusue, Y., Furukawa, T., Shikinami, Y., Okuno, M. and Nakamura, T.J. (1999). Bonding Behavior of Ultrahigh Strength Unsintered Hydroxyapatite Particles/Poly(L-lactide) Composites to Surface of Tibial Cortex in Rabbits, J. Biomed. Mater. Res., 47: 412-419.

13. Ignjatovic, N., Savic, V., Najman, S., Plavsic, M. and Uskokovic, D. (2001). A Study of HAp/PLLA Composite as a Subtitute for Bone Powder, using FT-IR Spectroscopy, Biomaterials, 22: 571-575.

14. Furukawa, T., Matsusue, Y., Yasunaga, T., Shikinami, Y., Okuno, M. and Nakamura, T. (2000). Biodegradation Behavior of Ultra-High-Strength Hydroxyapatite/Poly(L-lactide) Composite Rods for Internal Fixation of Bone Fractures, Biomaterials, 21: 889-898. 
15. Furukawa, T., Matsusue, Y., Yasunaga, T., Nakagawa, Y., Okada, Y., Shikinami, Y., Okuno, M. and Nakamura, T.J. (2000). Histomorphometric Study on High-strength Hydroxyapatite/Poly(L-lactide) Composite Rods for Internal Fixation of Bone Fractures, J. Biomed. Mater. Res., 50: 410-419.

16. Cehreli, C.M., Saime, S., Kesenci, K., Tuzlakoglu, K., Piskin, E., Özturk, S., Ruacan, S., Caner, B. and Bozkurt, F.M. (2003). Biological Reactions to a Poly(L-lactide)-Hydroxyapatite Composite: A Study in Canine Mandible, Journal of Biomaterials Applications, 17: 265-252.

17. Ong, J.L., Carnes, D.L. and Sogal, A. (1999). Effect of Transforming Growth Factor-beta on Osteoblast Cells Cultured on 3 Different Hydroxyapatite Surfaces, Int. J. Oral. Maxillofac. Implants, 14(2): 217-225.

18. Tsuruga, E., Takita, H., Itoh, H., Wakisaka, Y. and Kuboki, Y. (1997). Pore Size of Porous Hydroxyapatite as the Cell-substratum Controls BMPinduced Osteogenesis, J. Biochem., 121(2): 317-324. 